\title{
EXPLORING THE MIGRATION INTENTION OF ROMANIAN STUDENTS IN ECONOMICS
}

\section{Aurelian-Petruș Plopeanua ${ }^{\text {, Daniel Homocianu }}{ }^{\text {, }}$, Christiana Brigitte Sandu ${ }^{b}$, Elisabeta Jabab}

\begin{abstract}
In the context of increasing concerns about the demographic decline of Europe and the lack of sustainable policies to fight against it, the main purpose of this study is to estimate the migration intention of the Romanian students in economics and business administration and the influence of the determinant factors. Data are collected from a questionnaire survey applied to a sample of 1,155 students at the Alexandru Ioan Cuza University of Iasi. We have applied a multinomial logistic regression model with both simple effects and interactions. The results have brought strong arguments proving the importance of personal value recognition, beliefs and attitudes, family background, as well as interactions between genders, attitude towards competition and active search for a job or between parental severity and migration legacy, as determinant factors of the students' intention to migrate to Western Europe. These results may serve regional, national and even community-based sustainable development policies for the conservation of human resources and mostly of higher-educated individuals.
\end{abstract}

Keywords: migration intention, personal value recognition, parental role models, religious behaviour, individual liberty, interactions, multinomial logistic regression

JEL Classification: B23, F22, D91, Y10

\section{Introduction}

The European Union enlargement in Central and Eastern Europe made possible an increased labour mobility abroad (Galasińska and Kozłowska, 2009), especially to Western countries, generating a "new migration system" (Favell, 2008). The migration flows

a Alexandru Ioan Cuza University of Iasi, Institute of Interdisciplinary Research, Iasi, Romania

b Alexandru Ioan Cuza University of Iasi, Faculty of Economics and Business Administration, Iasi, Romania

Email: aurelian.plopeanu@feaa.uaic.ro,daniel.homocianu@feaa.uaic.ro, christiana.balan@uaic.ro, ejaba@uaic.ro 
are characterised by a brain drain, which includes migration of highly skilled workers (Docquier and Rapoport, 2012). These human capital categories, better equipped with specific skills, usually bring many advantages to receiving countries (Luthra et al., 2014). The effects of labour migration on the countries of origin are both positive and negative. The positive effects are seen in lower pressure on unemployment rates and the "migration premium", including remittances (Andrén and Roman, 2016; Balan et al., 2014), which stimulate local modernity and development (Hickey, 2016). The most important negative consequences are population decline, low fertility rates, increased demographic ageing, a high drain of labour force from strategic national systems (education and health systems) and loss of essential intellectual capital stocks and prior public investments in education (Akl et al., 2008).

The reasons behind the decision to migrate abroad could be determined by both pecuniary and non-pecuniary causes (Niedomysl, 2011). While the economic causes are common predictors for the migration intention, there are also deeper reasons for such behaviour. The migration decisions are not primarily determined by superior material rewards, but rather by individuals' inner motivations and traits (Krings et al., 2013). When considering the decision to migrate in the long run, recent studies highlight that it is not simply an individual choice based on subjective desires, but one mostly based on personal ambitions, higher opportunities and greater satisfactions (Van Mol and Timmerman, 2014).

An important non-pecuniary cause of migration intention is life dissatisfaction (Blanchflower and Shadforth, 2009). Consequently, individuals dissatisfied with their life have greater intention to migrate. Life satisfaction is also considered a mediator between migration intention and individual socioeconomic characteristics and macroeconomic conditions (Otrachshenko and Popova, 2014).

The intergenerational migration capital has important consequences for children's decision to migrate due to the psychological ease of taking into consideration a risky and uncomfortable opportunity (Ivlevs and King, 2012). This transfer of migration experience from parents to children generates a "snowball effect" towards further migration. Interpersonal relationships and social networks in the countries of destination (relationships between family members and friends) encourage the migration intention (Friberg, 2012).

Openness to new experiences is a personality trait that is responsible for behaviours related to flexibility and adaptability when moving to a new society or culture; therefore, it may influence the willingness to migrate (Canache et al., 2013). It has been highlighted that individuals with high scores of openness were successfully adapted to new jobs abroad (Huang et al., 2005). 
Individuals' social and demographic characteristics also influence the migration intention. Regarding employment status, unemployed individuals are less tempted to leave their country of origin (Williams et al., 2018), while, traditionally, it has been argued that male migration flows outnumber the female ones (Kanaiaupuni, 2000). Moreover, individuals with high levels of religiousness migrate to a lower extent to secular societies (Lewis and Kashyap, 2013).

In this paper, we aim to study the influence of several non-pecuniary factors on students' intention to migrate after graduation. We focus on the migration intention because it is a good proxy for the actual migration action, as individuals who intend to migrate actually decide to do so within five years (Boheim and Taylor, 2002). Furthermore, we emphasize a high correlation between migration intention and the actual decision to leave the country of origin (Creighton, 2013).

The migration problem in Romania has many features that make it specific. Different levels of development across various Romanian regions, including high unemployment rates, low income levels, poor education and unstable career prospects represent important triggers for the migration outflows, especially to the Western European countries. Other "push" factors for the migration phenomenon in Romania are represented by poor standards of living, low opportunities on the labour market and an increased dissatisfaction with the low quality of the political class, the inefficient bureaucracy and the endemic corruption in the interactions with public and private institutions. Moreover, other systemic aspects regarding the decision to leave Romania for other countries to study and work are based on individuals' and their families' financial difficulties (especially unpaid debts) or the desire to overcome the poverty. The need to reunite the family abroad when one family member previously emigrated or if close friends or other acquaintances are already settled abroad are other characteristics that may influence the migration phenomenon.

According to the International Migration Report (UN, 2015), Romania experienced one of the fastest average annual growth rates of emigrants between 2000 and 2015, 7.3\% annually, outnumbered only by Syria. Also, as emphasized in World Migration in Figures (OECD-UNDESA, 2013), starting with 2000, the Romanians' migration rates increased, especially for those who preferred OECD countries (+8.3\%). The International Migration Report (UN, 2017) highlighted that Romania had lost more than 3.58 million citizens as a result of their migration decision, especially to Western European countries. According to the World Bank Report (2018), working-age Romanian migrants abroad represented more than $20 \%$ of the working population in Romania.

The main objectives of the paper are to analyse the effects of a set of non-pecuniary factors on the migration intention in the case of Romanian students and to identify the most powerful influences. We study two distinct categories of these factors, namely individuals' 
and families' characteristics. The students' individual characteristics considered are age, gender, openness personality trait, personal desire for value recognition, interpersonal trust, liberty, religious behaviour, fear of competition and intention to become an employee. The family characteristics are parents' education, family income and parents' migration experience.

In order to analyse the influence of factors on the migration intention, we apply a multinomial regression analysis using STATA 13.0.

According to the main objectives of our study and based on results obtained by previous research into the migration intention, we formulated the following research hypotheses:

$H_{1}$ : Students who are more self-motivated and put a greater emphasis on personal value recognition are more likely to intend to migrate after graduation.

$H_{2}$ : Students who are less religious and manifest a higher level of interpersonal trust are more inclined to intend to migrate.

$H_{3}$ : Students who are more tempted to consider individual liberty as the main trigger of societal progress are more likely to intend to migrate.

$H_{4}$ : Students who benefit from different family backgrounds in terms of income, parental upbringing and migration experience, are more tempted to choose to migrate.

Below, we describe the population and the case selection, the methodology and measurement of variables in the second section. In the third section, we present the main results and we discuss the consistency of our findings in relation with previous research. Finally, in the conclusion section, we underline the importance of our empirical results and their possible impact on further research and sustainable migration policies.

\section{Data and Method}

\subsection{Population and sample}

Our study aims to measure the influence of non-pecuniary determinant factors on the migration intention after graduation among students at the Faculty of Economics and Business Administration of the Alexandru Ioan Cuza University (UAIC) of Iași, the oldest Romanian university. The geographical distribution of their residence location covers almost the entire eastern and north-eastern regions of Romania, with various standards of living.

The criterion for constructing the sample was based on the idea of random inclusion of students of both undergraduate and master programmes of study. From the total population of 7,093 enrolled students at the UAIC, we randomly sampled 1,155 students 
who were interviewed between December 2016 and February 2017. The sample size was calculated considering a $5 \%$ significance level and a $3 \%$ margin of error. The non-response rate was $4.76 \%$.

The data were collected through a questionnaire-based survey. Starting from a solid documentation and holding a clear and simple definition for every concept or item, we developed an appropriate set of closed-ended questions, structured into separate sections. The questions were kept as clear as possible. To receive an honest opinion from the respondents and avoid respondent bias, we included "cross-check" questions that allowed us to aim at an increased reliability of the questionnaire.

We chose to study the student population to estimate their intention to migrate abroad because they are usually more attracted to migrate abroad due to the fact that they have few responsibilities and are very tempted to search for better jobs, higher standards of living and recognition of their personal value.

\subsection{Method and variables}

In order to estimate the students' migration intention and to identify the determinant factors of this intention, we used a multinomial logistic regression (MNL regression).

When estimating a multinomial logistic model for a dependent variable with $J$ categories, we estimate $J-1$ logit equations, where each equation is a linear function that models the logarithm of probability of having a response $j$ to a predetermined baseline category $J$ (Agresti, 2002; Jaba, 2002). Our dependent variable ( $Y$ ) measures the migration intention (Do you intend to migrate to Western Europe after graduation?) and has three possible outcomes: No, I will not migrate (0), I do not know if I will migrate (1) and Yes, I will migrate (2). In our case, we designated No, I will not migrate (0) as the reference category and each of the other levels is compared with this reference.

The two logit equations of the MNL model are:

- the equation for the logit of Undecided (1):

$$
\operatorname{logit}\left(Y_{1}\right)=\ln \left[\frac{P(Y=1 \mid \boldsymbol{X})}{P(Y=0 \mid \boldsymbol{X})}\right]=\beta_{10}+\sum_{k=1}^{K} \beta_{1 k} X_{k},
$$

- $\quad$ the equation for the logit of Yes, I will migrate (2):

$$
\operatorname{logit}\left(Y_{2}\right)=\ln \left[\frac{P(Y=2 \mid \boldsymbol{X})}{P(Y=0 \mid \boldsymbol{X})}\right]=\beta_{20}+\sum_{k=1}^{K} \beta_{2 k} X_{k},
$$

where: $Y$ is the dependent variable; $X_{k}$ are the independent variables (predictors), with $k=1,2, \ldots, K$; and $\beta_{k}$ are the logit coefficients for each category of the dependent variable. 
Table 1: List of variables used in study

\begin{tabular}{|c|c|c|}
\hline Variables & Item in the questionnaire & Variable coding \\
\hline \multicolumn{3}{|c|}{ Individual characteristics } \\
\hline Age & How old are you? & Years \\
\hline Gender & Your gender is ....... & 1 - male, 0 - female \\
\hline Openness & $\begin{array}{l}\text { Are independence and creativity among the qualities that } \\
\text { you inherited from your parents? }\end{array}$ & $1-$ yes, $0-$ no \\
\hline $\begin{array}{l}\text { Personal value } \\
\text { recognition }\end{array}$ & $\begin{array}{l}\text { For you, is migrating to Western Europe equivalent with } \\
\text { the recognition of your personal value and, therefore, } \\
\text { to obtain what you want and deserve? }\end{array}$ & $1-$ yes, $0-$ no \\
\hline Interpersonal trust & $\begin{array}{l}\text { Generally speaking, would you consider that most people } \\
\text { can be trusted? }\end{array}$ & $\begin{array}{l}5 \text {-point Likert scale, } \\
\text { from } 1 \text { - complete distrust } \\
\text { to } 5 \text { - complete trust }\end{array}$ \\
\hline Individual liberty & Is individual liberty a factor of progress? & $1-$ yes, $0-$ no \\
\hline Religious behaviour & $\begin{array}{l}\text { How often do you participate in religious services? } \\
1 \text { - More than once a week / Once a week } \\
2 \text { - One to three times a month } \\
3 \text { - A few times a year } \\
4 \text { - Less often } \\
5 \text { - Never }\end{array}$ & $\begin{array}{l}1 \text { - religious behaviour } \\
\text { (if scores are } 1 \text { or } 2 \text { for this item), } \\
0 \text { - secular behaviour } \\
\text { (if scores are } 3,4 \text {, or } 5 \text { for this } \\
\text { item) }\end{array}$ \\
\hline Fear of competition & $\begin{array}{l}\text { Are you afraid to compete for a job or for an important } \\
\text { function? }\end{array}$ & $1-$ yes, $0-$ no \\
\hline Active job searching & $\begin{array}{l}\text { Are you looking for a part-time or full-time job } \\
\text { or for involvement as a volunteer? }\end{array}$ & $1-$ yes, $0-$ no \\
\hline \multicolumn{3}{|c|}{ Family Characteristics } \\
\hline $\begin{array}{l}\text { Household monthly } \\
\text { income level }\end{array}$ & What is your household monthly income level? & $\begin{array}{l}1 \text { - less than } 1500 \text { RON } \\
2 \text { - } 1500-2499 \\
7 \text { - more than } 6500 \text { RON }\end{array}$ \\
\hline $\begin{array}{l}\text { Mother's level } \\
\text { of education }\end{array}$ & $\begin{array}{l}\text { What is your mother's highest level } \\
\text { of education completed? }\end{array}$ & years of total schooling \\
\hline $\begin{array}{l}\text { Father's level } \\
\text { of education }\end{array}$ & $\begin{array}{l}\text { What is your father's highest level } \\
\text { of education completed? }\end{array}$ & years of total schooling \\
\hline Parental severity & How would you assess your parents' severity? & $\begin{array}{l}\text { 10-point Likert scale, } \\
\text { from } 1 \text { - very low severity } \\
\text { to } 10 \text { - very high severity }\end{array}$ \\
\hline $\begin{array}{l}\text { Mother previous } \\
\text { migration experience } \\
\text { for more than one year }\end{array}$ & $\begin{array}{l}\text { Has your mother been gone abroad for more } \\
\text { than one year? }\end{array}$ & $1-$ yes, $0-$ no \\
\hline $\begin{array}{l}\text { Father previous } \\
\text { migration experience } \\
\text { for more than one year }\end{array}$ & $\begin{array}{l}\text { Has your father been gone abroad for more } \\
\text { than one year? }\end{array}$ & $1-$ yes, $0-$ no \\
\hline
\end{tabular}

Source: Authors' own design

In order to interpret the influence of the explanatory variables on the migration intention, we used odds ratios. For calculating them, the exponential function of the MNL regression coefficients is usually considered (Hosmer and Lemeshow, 2000). To assess 
the effect of predictors across all levels of the outcome variable simultaneously, we used the likelihood ratio (LR) test (Kleinbaum and Klein, 2010). For evaluating the effect of the independent variables at a single outcome level, we applied the Wald test statistics.

We were also interested in the potential interactions between the independent variables. Consequently, we considered some of them in our MNL regression model.

The independent variables referring to students' individual and family characteristics that were considered to explain the intention to migrate are presented in Table 1.

The individual characteristics include: personality traits, such as openness; attitudes such as interpersonal trust, individual liberty, fear of competition; behaviours, such as religiosity and active job searching; and values, namely recognition of personal value. We admit that the latter is considered a non-pecuniary cause of migration, especially based on the attitudes and motivations regarding life dissatisfaction, general disappointment and lack of prospects, in combination with the feeling of exclusion, seen through the lenses of the lack of meritocracy in society.

The family characteristics refer to: social background, namely parents' education and household income and family environment, such as parental severity and migration experience abroad.

\section{Results and Discussion}

\subsection{Sample description}

The summary statistics for the variables considered in the study are shown in the Appendix. In terms of migration intention, the results for our sample show that $24 \%$ of the students declared their clear intention, $43.36 \%$ were undecided, whereas $32.64 \%$ did not plan to migrate. In our sample, $26.35 \%$ of male students and $23.06 \%$ of female ones expressed their intention to migrate.

Moreover, among the respondents who emphasized the importance of personal value recognition in their decision to migrate after graduation, more than half (58.78\%) confirmed their intention, while among those who did not consider this variable as a propensity factor to migrate only $13.13 \%$ actually plan to migrate to Western Europe. Furthermore, we can notice a higher percentage of students who intend to migrate among those who have a secular behaviour (27.02\%) in comparison with the religious group (19.09\%). 
The same pattern of migration intention can be observed in relation to the perception of the role of individual liberty for progress. Among the students who consider individual liberty an important motivation, $26.46 \%$ declared the willingness to migrate after graduation, while, from the group that did not consider it a driving force in their lives, only $17.83 \%$ expressed their intention to migrate.

The average age of the students who are eager to migrate is 20.22 years, while, for the overall sample, it is equal to 20.67 years.

For the group of students that intend to migrate, we may note a lower average score of household income and also a higher average score of parental severity compared to the other two groups, the undecided and the migration-reluctant students.

\subsection{Predictors for students' migration intention}

In order to identify the factors affecting the students' migration intention and estimate the influence of the considered factors, we applied an MNL regression analysis. The coefficients are estimated as logarithms of odds ratios of the two Yes versus No migration intention and Undecided versus No migration intention equations. To underline the strongest main influences on the students' intention to migrate, we estimated the simple effects of the independent variables. For a more in-depth approach, due to possible interactions among individual characteristics and family ones that affect the migration intention, we built an interaction effects model.

Initially, we estimated a general model assessing the influence of all 16 independent variables on the outcome variable, the migration intention (Table 2). The approach used to build the model involved three consecutive stages.

In the first stage, we included one explanatory variable, namely recognition of personal value, as the most important trigger of migration according to the first research hypothesis $H_{1}$ (Table 2, scenario $a$ - Equation 2, and scenario $d$ - Equation 1).

Secondly, we introduced in the equations a set of explanatory variables defining the students' individual characteristics (Table 2, scenario $b-$ Equation 2, and scenario $e-$ Equation 1).

Finally, we enriched the model by including a second set of explanatory variables assessing the students' family characteristics (Table 2, scenario $c-$ Equation 2, and scenario $f$ - Equation 1). 
Table 2: MNL estimations (Ln of odds ratios) of migration intention - simple effects model

\begin{tabular}{|c|c|c|c|c|c|c|}
\hline \multirow[t]{2}{*}{ Variables } & \multicolumn{3}{|c|}{$\begin{array}{c}\text { Equation } 2 \text { - Migration intention: } \\
\text { Yes versus No }\end{array}$} & \multicolumn{3}{|c|}{$\begin{array}{c}\text { Equation } 1 \text { - Migration intention: } \\
\text { Undecided versus No }\end{array}$} \\
\hline & (a) & (b) & (c) & (d) & (e) & (f) \\
\hline $\begin{array}{l}\text { Personal value } \\
\text { recognition }\end{array}$ & $\begin{array}{l}3.40^{* * *} \\
(0.28)\end{array}$ & $\begin{array}{l}3.40^{* * * *} \\
(0.29)\end{array}$ & $\begin{array}{l}3.38^{* * * *} \\
(0.29)\end{array}$ & $\begin{array}{l}1.63^{* * *} \\
(0.28)\end{array}$ & $\begin{array}{l}1.63^{* * *} \\
(0.28)\end{array}$ & $\begin{array}{l}1.60^{* * *} \\
(0.29)\end{array}$ \\
\hline Age & - & $\begin{array}{l}-0.11^{* * *} \\
(0.04)\end{array}$ & $\begin{array}{l}-0.11 * * * \\
(0.04)\end{array}$ & - & $\begin{array}{l}-0.08^{* * *} \\
(0.03)\end{array}$ & $\begin{array}{l}-0.08^{* * *} \\
(0.03)\end{array}$ \\
\hline Openness & - & $\begin{array}{l}-0.01 \\
(0.19)\end{array}$ & $\begin{array}{c}0.03 \\
(0.20)\end{array}$ & - & $\begin{array}{l}0.25^{*} \\
(0.15)\end{array}$ & $\begin{array}{l}0.28^{*} \\
(0.15)\end{array}$ \\
\hline Interpersonal trust & - & $\begin{array}{l}-0.29 * * \\
(0.11)\end{array}$ & $\begin{array}{l}-0.29 * * * \\
(0.11)\end{array}$ & - & $\begin{array}{l}-0.06 \\
(0.09)\end{array}$ & $\begin{array}{l}-0.06 \\
(0.09)\end{array}$ \\
\hline Religious behaviour & - & $\begin{array}{l}-0.70^{* * *} \\
(0.20)\end{array}$ & $\begin{array}{c}-0.72 * * * \\
(0.21)\end{array}$ & - & $\begin{array}{l}-0.23 \\
(0.15)\end{array}$ & $\begin{array}{c}-0.28^{*} \\
(0.15)\end{array}$ \\
\hline Individual liberty & - & $\begin{array}{l}0.39 * \\
(0.22)\end{array}$ & $\begin{array}{l}0.41^{*} \\
(0.22)\end{array}$ & - & $\begin{array}{l}-0.14 \\
(0.16)\end{array}$ & $\begin{array}{l}-0.15 \\
(0.16)\end{array}$ \\
\hline $\begin{array}{l}\text { Household income } \\
\text { level }\end{array}$ & - & - & $\begin{array}{l}-0.14^{* *} \\
(0.07)\end{array}$ & - & - & $\begin{array}{c}-0.10^{* *} \\
(0.05)\end{array}$ \\
\hline Mother's education & - & - & $\begin{array}{l}0.13^{* * *} \\
(0.05)\end{array}$ & - & - & $\begin{array}{l}0.06^{*} \\
(0.04)\end{array}$ \\
\hline Parental severity & - & - & $\begin{array}{l}0.07^{*} \\
(0.04)\end{array}$ & - & - & $\begin{array}{c}0.02 \\
(0.03)\end{array}$ \\
\hline $\begin{array}{l}\text { Both parents gone } \\
\text { abroad }\end{array}$ & - & - & $\begin{array}{l}0.62^{* *} \\
(0.30)\end{array}$ & - & - & $\begin{array}{l}0.43^{*} \\
(0.25)\end{array}$ \\
\hline $\begin{array}{l}\text { Only father gone } \\
\text { abroad }\end{array}$ & - & - & $\begin{array}{l}0.45^{*} \\
(0.26)\end{array}$ & - & - & $\begin{array}{l}0.42^{* *} \\
(0.20)\end{array}$ \\
\hline Constant & $\begin{array}{l}-1.14^{* * *} \\
(0.11)\end{array}$ & $\begin{array}{c}1.17 \\
(0.85)\end{array}$ & $\begin{array}{l}-0.27 \\
(1.04)\end{array}$ & $\begin{array}{c}0.12 \\
(0.07) \\
\end{array}$ & $\begin{array}{l}1.71^{* * *} \\
(0.60)\end{array}$ & $\begin{array}{l}1.43^{*} \\
(0.75) \\
\end{array}$ \\
\hline Observations & 1,100 & 1,096 & 1,094 & 1,100 & 1,096 & 1,094 \\
\hline LR chi2 (df) & 250.51 & 306.29 & 330.26 & 250.51 & 306.29 & 330.26 \\
\hline Df & 2 & 18 & 32 & 2 & 18 & 32 \\
\hline Prob > chi2 & 0.0000 & 0.0000 & 0.0000 & 0.0000 & 0.0000 & 0.0000 \\
\hline Pseudo R square & 0.1064 & 0.1305 & 0.1409 & 0.1064 & 0.1305 & 0.1409 \\
\hline AUC (ROC) & 0.8272 & 0.9235 & 0.9261 & 0.8272 & 0.9235 & 0.9261 \\
\hline
\end{tabular}

Note 1: The variable corresponding to recognition of personal value was identified as the strongest predictor of the students' migration intention, using three classifying algorithms (Decision Trees, Neural Networks and Naïve Bayes) available in the Microsoft Excel Data Mining add-in working with SQL Server Analysis Services. All three suggest personal value recognition as the core variable of the model. Note 2: Only the variables (corresponding lines) having a significant influence at least for one set of specifications / scenario (corresponding columns) were left in this table.

Note 3: Standard errors in parentheses; ${ }^{*} p<0.1,{ }^{* *} p<0.05,{ }^{* * *} p<0.01$.

Source: Authors' own calculations in STATA 13.0 
In all these three stages, the results indicated Personal value recognition as the core variable, having the highest effect on students' migration intention (Table 2, both Yes versus No - Equation 2 and Undecided versus No - Equation 1). The students that consider personal value recognition a key trigger for migrating are more likely to migrate after graduation rather than stay in their country, as compared to the students who do not put an emphasis on personal value recognition. Moreover, the results show an increased likelihood to be undecided about migrating to Western Europe rather than staying in Romania for the students who appreciate that migration is equivalent to personal value recognition and getting what they deserve as compared to the other students. The effect of the core variable is significant and robust across all six scenarios (Table 2, scenarios $a$, $b$ and $c-$ Equation 2, and $d, e$ and $f$ - Equation 1).

These results, which indicate that students inclined more to place a great emphasis on the recognition of their personal value are more likely to migrate, validate the first hypothesis, H1. These findings are consistent with the ones from another study focused on a different target population represented by students in Theology (Plopeanu et al., 2018).

In addition, for the rest of the individual characteristics, we can see that the likelihood of migrating to Western Europe rather than staying in Romania decreases with age, interpersonal trust, and religious behaviour. The same likelihood increases for the students who value individual liberty as a factor of progress in society.

However, gender, as well as competition aversion and active job searching, have no significant effect on the migration intention when all three are considered individually, while openness has a significant positive influence only for the undecided subjects. For the students who are open to new experiences, the odds of being undecided about migration rather than staying in their country increase slightly compared to the students who are not open-minded.

The estimated influences of the individual characteristics on the migration intention allow us to partially validate hypothesis $H_{2}$. We assumed that less religious and more confident students are more likely to migrate. The results show that the likelihood to intend to migrate (only the clear intention - Yes versus No, Equation 2) is higher for students who are less religious and manifest a lower degree of interpersonal trust (Table 2, scenarios $b$ and $c-$ Equation 2, and scenarios $e$ and $f$ - Equation 1). These results are consistent with the findings of Docquier et al. (2017, p. 1) who concluded that individuals who intend to migrate to OECD countries exhibit significantly lower levels of religiosity than the rest of the population.

Moreover, we assumed that the students who put a greater emphasis on individual liberty as an important factor of progress (hypothesis $H_{3}$ ) are more likely to intend to migrate. The results validate hypothesis $H_{3}$ only in terms of the clear intention to migrate (Yes versus No, Equation 2) (Table 2, scenarios $b$ and $c$ - Equation 2, and scenarios $e$ and $f$ - 
Equation 1). Our findings are in line with the conclusions of Suciu et al. (2017), who emphasize that migration is an expression of liberty and individual choice.

Furthermore, the extended model also includes a set of predictors referring to the family characteristics (Table 2, $3^{\text {rd }}$ stage, scenario $c$-Equation 2, and scenario $f$-Equation 1). Among this set, mothers' education and parents' migration experience show positive influences on the students' likelihood to migrate after graduation. In addition, students who experienced more severe upbringing are more likely to migrate to Western Europe rather than stay in Romania. However, the household monthly income has a negative impact on students' migration intention. The students who come from wealthier families are less likely to migrate after graduation rather than stay, compared to the students from less wealthy ones. An interesting result concerns the impact of parents' migration experience on the students' migration intention. For the students who have both parents gone abroad or only their father, the likelihood of migrating after graduation rather than staying in Romania is higher compared to students whose parents are not migrants. This influence is also significant on the likelihood of being undecided about migrating rather than staying. However, the students' migration intention to Western Europe is not fostered by their mothers' migration behaviour.

The values for the area under the curve of the receiver operating characteristic AUC (ROC), in Table 2, are high for all specified scenarios and both equations, indicating the validity of the set of predictors for the students' intention to migrate after graduation.

The resulting influences of the family characteristics on the students' migration intention confirm hypothesis $H_{4}$. The students from lower-income families, those with more educated parents and with parental migration experience for more than one year, are more likely to migrate. These findings are in line with those of Roman and Vasilescu (2016), indicating that teenagers are eager to migrate for better career opportunities, superior standards of living, and improved welfare.

Based on the results obtained from the general model (Table 2), we identified the explanatory variables with significant influence on the outcome variable. Further, we estimated a new refined model (Table 3), starting from the general model initially considered and applying the stepwise procedure.

All these ten influences obtained when deriving a new refined model (Table 3) are found among the eleven most significant ones from the previous model (Table 2, scenario $c$ - Equation 2, and scenario $f$ - Equation 1). The only difference consists in the lack of the influence corresponding to the parental severity in the refined model. This is explainable if admitting the slowest magnitude and lower edge significance in the previous model and the overall increased ROC in the refined one. 
Table 3: MNL estimations (Ln of odds ratios) of migration intention - new refined simple effects model using the stepwise procedure with backward selection

\begin{tabular}{|c|c|c|}
\hline Variables & $\begin{array}{c}\text { Equation } 2 \text { - Migration } \\
\text { intention: } \\
\text { Yes versus No }\end{array}$ & $\begin{array}{c}\text { Equation } 1 \text { - Migration } \\
\text { intention: } \\
\text { Undecided versus No }\end{array}$ \\
\hline Personal value recognition & $\begin{array}{l}3.39 * * * \\
(0.29)\end{array}$ & $\begin{array}{l}1.61^{* * *} \\
(0.28)\end{array}$ \\
\hline Age & $\begin{array}{l}-0.11^{* * *} \\
(0.04)\end{array}$ & $\begin{array}{c}-0.08^{* * *} \\
(0.03)\end{array}$ \\
\hline Openness & $\begin{array}{c}0.04 \\
(0.19)\end{array}$ & $\begin{array}{l}0.29 * \\
(0.15)\end{array}$ \\
\hline Interpersonal trust & $\begin{array}{l}-0.29^{* * *} \\
(0.11)\end{array}$ & $\begin{array}{l}-0.07 \\
(0.09)\end{array}$ \\
\hline Religious behaviour & $\begin{array}{c}-0.71^{* * *} \\
(0.20)\end{array}$ & $\begin{array}{c}-0.24 \\
(0.15)\end{array}$ \\
\hline Individual liberty & $\begin{array}{l}0.38^{*} \\
(0.22)\end{array}$ & $\begin{array}{l}-0.14 \\
(0.16)\end{array}$ \\
\hline Household income level & $\begin{array}{c}-0.15^{* *} \\
(0.06)\end{array}$ & $\begin{array}{c}-0.12^{* *} \\
(0.05)\end{array}$ \\
\hline Mother's education & $\begin{array}{c}0.10^{* * *} \\
(0.04)\end{array}$ & $\begin{array}{c}0.02 \\
(0.03)\end{array}$ \\
\hline Both parents gone abroad & $\begin{array}{l}0.56^{*} \\
(0.30)\end{array}$ & $\begin{array}{l}0.44^{*} \\
(0.24)\end{array}$ \\
\hline Only father gone abroad & $\begin{array}{l}0.43^{*} \\
(0.26)\end{array}$ & $\begin{array}{c}0.39 * * \\
(0.20)\end{array}$ \\
\hline Constant & $\begin{array}{c}0.01 \\
(0.93)\end{array}$ & $\begin{array}{l}1.65^{* *} \\
(0.67)\end{array}$ \\
\hline Observations & \multicolumn{2}{|c|}{1,094} \\
\hline LR chi2 (df) & \multicolumn{2}{|c|}{317.83} \\
\hline Df & \multicolumn{2}{|r|}{20} \\
\hline Prob > chi2 & \multicolumn{2}{|c|}{0.0000} \\
\hline Pseudo R square & \multicolumn{2}{|c|}{0.1356} \\
\hline AUC(ROC) & \multicolumn{2}{|c|}{0.9464} \\
\hline
\end{tabular}

Note: see Note 1 in Table 2.Standard errors in parentheses; ${ }^{*} p<0.1,{ }^{* *} p<0.05,{ }^{* *} p<0.01$.

Source: Authors' own calculations in STATA 13.0 
The estimates of the area under the ROC curve as a diagnostic test for our refined MNL model by using Peterson's (2010) shared code in STATA 13.0 (any new session using default settings) indicate a value of approximately 0.95 , which suggests a very good accuracy (Figure 1).

Figure 1: Area under the ROC curve for the new refined model

0.9463362140134262

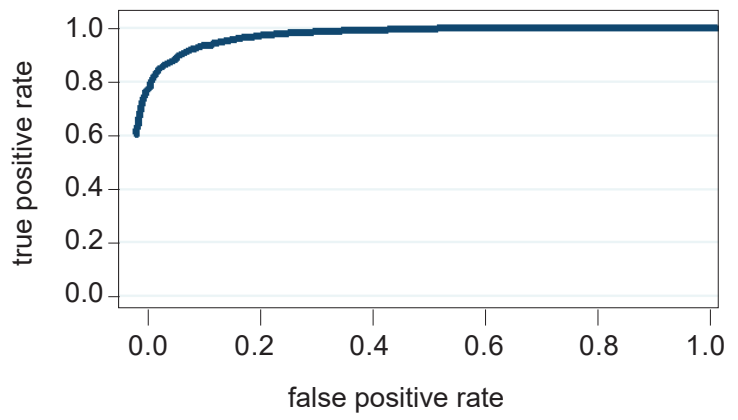

Source: Authors' own calculations in STATA 13.0

The relative importance of the predictors on the intention to migrate in terms of comparable effects considering the refined model is highlighted in Figure 2.

Figure 2: Relative importance of predictors in the refined model (MNL estimations: standardized coefficients)

\begin{tabular}{|c|c|c|c|c|c|c|c|}
\hline & & & bStd $=b^{*}$ & d.Dev.o & f $X$ & $\mathrm{e}^{\wedge} \mathrm{bStdX}=\mathrm{ex}$ & Std.Dev.of X) \\
\hline & $\begin{array}{c}\text { Std. } \\
\text { Dev.of X }\end{array}$ & $\begin{array}{l}\text { Mig } \\
\text { inte } \\
\text { Yes }\end{array}$ & $\begin{array}{l}\text { gration } \\
\text { ention: } \\
\text { vs. No }\end{array}$ & $\begin{array}{r}\text { Mic } \\
\text { int } \\
\text { Undec }\end{array}$ & $\begin{array}{l}\text { gration } \\
\text { ention: } \\
\text { ided vs. No }\end{array}$ & $\begin{array}{c}\begin{array}{c}\text { Migration } \\
\text { intention }\end{array} \\
\text { Yes vs. No }\end{array}$ & $\begin{array}{l}\text { Migration } \\
\text { intention } \\
\text { Undecided } \\
\text { vs. No }\end{array}$ \\
\hline Personal value recognition & $(0.43)$ & & $1.44 * * *$ & & $0.69 * * *$ & $4.23 * * *$ & $1.99 * * *$ \\
\hline Age & $(3.07)$ & -0.33 & $* * *$ & -0.25 & *** & $0.72 * * *$ & $0.78 * * *$ \\
\hline Openness & $(0.49)$ & & 0.02 & & $0.14 *$ & 1.021 & $1.15 *$ \\
\hline Interpersonal trust & $(0.86)$ & -0.25 & $* * *$ & -0.06 & & $0.78 * * *$ & 0.943 \\
\hline Religious behaviour & $(0.49)$ & -0.34 & $* * *$ & -0.12 & & $0.71 * * *$ & 0.89 \\
\hline Individual liberty & $(0.45)$ & & $0.17^{*}$ & -0.06 & & $1.19 *$ & 0.94 \\
\hline Household income level & $(0.64)$ & -0.24 & ** & -0.19 & ** & $0.79 * *$ & $0.83 * *$ \\
\hline Mother's education & $(0.63)$ & & $0.27 * * *$ & & 0.06 & $1.32 * * *$ & 1.065 \\
\hline Both parents gone abroad & $(0.33)$ & & $0.18 *$ & & $0.14 *$ & $1.20 *$ & $1.15^{*}$ \\
\hline Only father gone abroad & $(0.39)$ & & $0.16 *$ & & $0.15 * *$ & $1.18 *$ & $1.16 * *$ \\
\hline
\end{tabular}

Note: The bars on the left / right correspond to negative / positive influences, respectively. Standard deviation of explanatory variables in parentheses; ${ }^{*} p<0.1,{ }^{* *} p<0.05,{ }^{* *} p<0.01$

Source: Authors' own calculations in STATA 13.0 
Thus, it can be noticed that one standard deviation increase in the core variable-Personal value recognition - produces, on average, the most consistent effect, namely multiplies the odds of getting a clear intention to migrate rather than stay by 4.23 and the odds of being undecided regarding this intention rather than stay by 1.99 .

However, the need for a better and clearer understanding of the phenomenon of the migration intention has prompted us to undertake an in-depth exploration, especially when we admit possible hidden effects of predictors that do not manifest when they are considered alone. Therefore, this new perspective has led us to estimate the influences of the interactions between these variables (Table 4). First, we tested whether gender, when combined with other predictors, could possibly have a significant impact on students' migration intention. We also verified whether mothers' migration experience has a significant interaction effect on the migration intention.

In order to construct the interactions among predictors, we previously transformed the initial numeric independent variables into dummy variables $(1-$ yes, $0-$ no), considering a threshold based on their average values.

For defining the dummy variables, we considered the sign of the corresponding simple effects (Table 2). The variables with positive effects were recoded into above-average dummy variables: high parental severity and mother's and father's tertiary education. The variables with negative influences were recoded into below-average dummy variables: under 21 years, low interpersonal trust and low income level.

The results of the interaction effects model highlight that male students with no fear of competition and active job search orientation are more likely to migrate rather than stay in Romania compared to male students who a have fear of competition and are not active job searchers (Table 4, scenario $b$-Equation 2, male with a fear of competition and not looking for a job as the reference category). The likelihood of being undecided about migrating rather that staying in the country of origin is higher for male students who have no fear of competition and are active job search oriented (Table 4, scenario $e$-Equation 1).

Another significant interaction effect shows that students who have had a more severe parental upbringing and only the mother gone abroad for more than one year are more likely to migrate rather than stay, compared to students with a less severe parental upbringing and no maternal migration experience (Table 4, scenario $c$ - Equation 2, low parental severity and not only mother gone abroad set as the reference category). This interaction effect is weak and not statistically significant in the case of being undecided about migrating rather than staying. 
Table 4: MNL estimations (Ln of odds ratios) of migration intention - interaction effects model

\begin{tabular}{|c|c|c|c|c|c|c|}
\hline \multirow[t]{2}{*}{ Variables } & \multicolumn{3}{|c|}{$\begin{array}{c}\text { Equation } 2 \text { - Migration intention: } \\
\text { Yes versus No }\end{array}$} & \multicolumn{3}{|c|}{$\begin{array}{c}\text { Equation } 1 \text { - Migration intention: } \\
\text { Undecided versus No }\end{array}$} \\
\hline & (a) & (b) & (c) & (d) & (e) & (f) \\
\hline Personal value recognition & $\begin{array}{l}3.36^{* * *} \\
(0.29)\end{array}$ & $\begin{array}{l}3.39 * * * \\
(0.29)\end{array}$ & $\begin{array}{l}3.41^{* * *} \\
(0.29)\end{array}$ & $\begin{array}{l}1.57^{* * *} \\
(0.28)\end{array}$ & $\begin{array}{l}1.60 * * * \\
(0.28)\end{array}$ & $\begin{array}{l}1.61^{* * *} \\
(0.29)\end{array}$ \\
\hline Under 21 years & $\begin{array}{l}0.39^{*} \\
(0.20)\end{array}$ & $\begin{array}{l}0.41^{* *} \\
(0.20)\end{array}$ & $\begin{array}{l}0.41^{* *} \\
(0.20)\end{array}$ & $\begin{array}{l}0.36^{* *} \\
(0.15)\end{array}$ & $\begin{array}{l}0.39 * * \\
(0.15)\end{array}$ & $\begin{array}{l}0.38^{* *} \\
(0.15)\end{array}$ \\
\hline Openness & $\begin{array}{l}-0.03 \\
(0.19)\end{array}$ & $\begin{array}{l}-0.03 \\
(0.20)\end{array}$ & $\begin{array}{l}-0.03 \\
(0.20)\end{array}$ & $\begin{array}{l}0.26^{*} \\
(0.15)\end{array}$ & $\begin{array}{l}0.25^{*} \\
(0.15)\end{array}$ & $\begin{array}{l}0.25^{*} \\
(0.15)\end{array}$ \\
\hline Low interpersonal trust & $\begin{array}{l}0.52^{* * *} \\
(0.19)\end{array}$ & $\begin{array}{l}0.52^{* * *} \\
(0.19)\end{array}$ & $\begin{array}{l}0.50^{* *} \\
(0.20)\end{array}$ & $\begin{array}{c}0.12 \\
(0.15)\end{array}$ & $\begin{array}{l}0.13 \\
(0.15)\end{array}$ & $\begin{array}{c}0.11 \\
(0.15)\end{array}$ \\
\hline Religious behaviour & $\begin{array}{c}-0.68^{* * *} \\
(0.21)\end{array}$ & $\begin{array}{c}-0.66^{* * *} \\
(0.21)\end{array}$ & $\begin{array}{c}-0.67^{* * *} \\
(0.21)\end{array}$ & $\begin{array}{l}-0.25 \\
(0.15)\end{array}$ & $\begin{array}{l}-0.23 \\
(0.15)\end{array}$ & $\begin{array}{l}-0.24 \\
(0.15)\end{array}$ \\
\hline Individual liberty & $\begin{array}{l}0.40^{*} \\
(0.22)\end{array}$ & $\begin{array}{l}0.39 * \\
(0.22)\end{array}$ & $\begin{array}{l}0.40^{*} \\
(0.22)\end{array}$ & $\begin{array}{l}-0.16 \\
(0.16)\end{array}$ & $\begin{array}{l}-0.18 \\
(0.16)\end{array}$ & $\begin{array}{l}-0.17 \\
(0.16)\end{array}$ \\
\hline Low income level & $\begin{array}{l}0.40 * \\
(0.20)\end{array}$ & $\begin{array}{l}0.40^{* *} \\
(0.20)\end{array}$ & $\begin{array}{l}0.42^{* *} \\
(0.21)\end{array}$ & $\begin{array}{c}0.14 \\
(0.15)\end{array}$ & $\begin{array}{c}0.14 \\
(0.16)\end{array}$ & $\begin{array}{c}0.14 \\
(0.16)\end{array}$ \\
\hline Mother's tertiary education & $\begin{array}{l}1.06^{* * *} \\
(0.29)\end{array}$ & $\begin{array}{l}1.03^{* * *} \\
(0.29)\end{array}$ & $\begin{array}{l}1.05^{* * *} \\
(0.29)\end{array}$ & $\begin{array}{l}0.42^{*} \\
(0.23)\end{array}$ & $\begin{array}{c}0.38 \\
(0.24)\end{array}$ & $\begin{array}{c}0.39 \\
(0.24)\end{array}$ \\
\hline Father's tertiary education & $\begin{array}{l}-0.45 \\
(0.30)\end{array}$ & $\begin{array}{l}-0.43 \\
(0.31)\end{array}$ & $\begin{array}{l}-0.45 \\
(0.31)\end{array}$ & $\begin{array}{c}-0.51^{* *} \\
(0.24)\end{array}$ & $\begin{array}{c}-0.48^{* *} \\
(0.24)\end{array}$ & $\begin{array}{c}-0.48^{* *} \\
(0.24)\end{array}$ \\
\hline Both parents gone abroad & $\begin{array}{l}0.59 * \\
(0.30)\end{array}$ & $\begin{array}{l}0.57^{*} \\
(0.30)\end{array}$ & $\begin{array}{l}0.56^{*} \\
(0.30)\end{array}$ & $\begin{array}{c}0.40 \\
(0.25)\end{array}$ & $\begin{array}{c}0.38 \\
(0.25)\end{array}$ & $\begin{array}{c}0.38 \\
(0.25)\end{array}$ \\
\hline Only father gone abroad & $\begin{array}{c}0.42 \\
(0.26)\end{array}$ & $\begin{array}{c}0.39 \\
(0.26)\end{array}$ & $\begin{array}{c}0.39 \\
(0.26)\end{array}$ & $\begin{array}{l}0.37^{*} \\
(0.20)\end{array}$ & $\begin{array}{c}0.33 \\
(0.20)\end{array}$ & $\begin{array}{c}0.33 \\
(0.20)\end{array}$ \\
\hline $\begin{array}{l}\text { Female * Fear of competition * } \\
\text { Looking for a job }\end{array}$ & - & $\begin{array}{c}0.84 \\
(0.52)\end{array}$ & $\begin{array}{c}0.85 \\
(0.52)\end{array}$ & - & $\begin{array}{l}0.98^{* *} \\
(0.41)\end{array}$ & $\begin{array}{l}0.99 * * \\
(0.41)\end{array}$ \\
\hline $\begin{array}{l}\text { Male * No fear of competition * } \\
\text { Looking for a job }\end{array}$ & - & $\begin{array}{l}1.05^{*} \\
(0.58)\end{array}$ & $\begin{array}{l}1.09 * \\
(0.58)\end{array}$ & - & $\begin{array}{l}0.93^{* *} \\
(0.47)\end{array}$ & $\begin{array}{l}0.96^{* *} \\
(0.47)\end{array}$ \\
\hline $\begin{array}{l}\text { High parental severity * Only } \\
\text { mother gone abroad }\end{array}$ & - & - & $\begin{array}{l}0.75^{*} \\
(0.44)\end{array}$ & - & - & $\begin{array}{l}-0.51 \\
(0.36)\end{array}$ \\
\hline Constant & $\begin{array}{c}-2.63^{* * *} \\
(0.38)\end{array}$ & $\begin{array}{l}-3.18^{* * *} \\
(0.59)\end{array}$ & $\begin{array}{l}-3.12^{* * *} \\
(0.59)\end{array}$ & $\begin{array}{l}-0.50^{*} \\
(0.27)\end{array}$ & $\begin{array}{c}-0.97^{* *} \\
(0.44)\end{array}$ & $\begin{array}{c}-0.94^{* *} \\
(0.44)\end{array}$ \\
\hline Observations & 1,094 & 1,094 & 1,094 & 1,094 & 1,094 & 1,094 \\
\hline LR chi2 (df) & 324.85 & 333.99 & 337.72 & 324.85 & 333.99 & 337.72 \\
\hline Df & 32 & 40 & 42 & 32 & 40 & 42 \\
\hline Prob > chi2 & 0.0000 & 0.0000 & 0.0000 & 0.0000 & 0.0000 & 0.0000 \\
\hline Pseudo R square & 0.1386 & 0.1425 & 0.1441 & 0.1386 & 0.1425 & 0.1441 \\
\hline
\end{tabular}

Note: see Notes 1 and 2 in Table 2. Standard errors in parentheses; ${ }^{*} p<0.1, * * p<0.05,{ }^{* * *} p<0.01$

Source: Authors' own calculations in STATA 13.0 
The results, confirming the significant effects of the interaction between high parental severity and the case when only mothers have left abroad for more than one year, are in line with other previous studies. Zumbuehl et al. (2018) stressed that parents who are more involved in the upbringing of their children transmit more strongly their own attitudes with respect to risk and trust.

It is important to highlight that our results are based on studying the migration intention only among the students of one academic centre, namely the Alexandru Ioan Cuza University of Iasi. Consequently, the corresponding migration intention model and its findings are specific to a population from the eastern and north-eastern regions of Romania. It could be valuable to test the results of this research on other populations considering other regions of Romania, or even different countries and fields of study other than economics.

\section{Conclusions}

This study aimed to explore the factors that may influence the migration intention or indecision in opposition to the intention not to migrate in the future, among students enrolled in Economics.

The results outline that recognition of personal value, an integrative and very strong motivation for leaving the country of origin, is the most powerful and reliable predictor for planning to migrate and it significantly increases this probability. Moreover, both the level of religiousness and of interpersonal trust negatively and significantly influence the intention to migrate to Western European countries. The emphasis on individual liberty as the main cause of progress has a positive impact on such an intention. Parental and paternal migration experience abroad for at least one year and mothers' tertiary education attainment are other positive predictors of the offspring's future decisions to migrate. In addition, other variables have been tested in this article, leading to a conclusion that a high level of family income and a higher age negatively influence the migration intention, albeit with lower magnitudes.

An in-depth approach based on interactions between variables revealed interesting findings. Firstly, male students who are not afraid to compete for a job or for an important position and who are actively searching for it are more likely to intend to migrate after graduation. Secondly, the students who have more severe parents and mothers in a situation of having migrated abroad for more than one year are more inclined to choose such a decision in the future.

Although our study is limited to the students of Economics at the Alexandru Ioan Cuza University of Iasi, further research may reveal valuable findings, especially when 
taking into consideration other Romanian universities and fields of study. Therefore, we aim to validate in the future whether these results are similar when exploring higher population samples from several regions.

The implications of this article are also taken into consideration. The main reason why the students intend to migrate after graduation is somehow related to what they value the most: personal value recognition, personal fulfilment and social expectations in creating a meritocratic environment in which young adults can accomplish their careers and life aspirations. The importance of personal motivations, attitudes, beliefs and values may shape the probability of intending to migrate abroad. Consequently, the policy makers' desire to understand the emigration phenomenon and actively search for sustainable policies to retain cohorts of valuable and educated individuals must take account of these characteristics with high explanatory power. 


\section{Appendix: Summary statistics for variables considered in this study}

\section{OUTCOME VARIABLE}

\begin{tabular}{|c|c|c|c|c|}
\hline $\begin{array}{l}\text { Migration intention N (\%) } \\
\text { Yes, I will migrate (2) } \\
\text { I do not know (1) } \\
\text { No (0) }\end{array}$ & $\begin{array}{l}264(24.00 \%) \\
477(43.36 \%) \\
359(32.64 \%)\end{array}$ & & & \\
\hline EXPLANATORY VARIABLES & Overall sample & $\begin{array}{l}\text { Migration intention: } \\
\text { Yes, I will migrate (2) }\end{array}$ & $\begin{array}{l}\text { Migration intention: } \\
\text { I do not know (1) }\end{array}$ & $\begin{array}{c}\text { Migration intention: } \\
\text { No }(0)\end{array}$ \\
\hline \multicolumn{5}{|c|}{ INDIVIDUAL CHARACTERISTICS } \\
\hline Age mean $(95 \% \mathrm{Cl})$ & $20.67(20.49 ; 20.85)$ & $20.22(19.98 ; 20.46)$ & $20.43(20.21 ; 20.66)$ & $21.31(20.87 ; 21.74)$ \\
\hline \multicolumn{5}{|l|}{ Gender N (\%) } \\
\hline Male (1) & $315(28.64 \%)$ & $83(26.35 \%)$ & $123(39.05 \%)$ & $109(30.40 \%)$ \\
\hline Female (0) & $785(71.36 \%)$ & $181(23.06 \%)$ & $354(45.10 \%)$ & $250(31.85 \%)$ \\
\hline \multicolumn{5}{|l|}{ Openness N (\%) } \\
\hline Yes (1) & $657(59.73 \%)$ & $155(23.59 \%)$ & $299(45.51 \%)$ & $203(30.89 \%)$ \\
\hline No $(0)$ & $443(40.27 \%)$ & 109 (24.60\%) & $178(40.18 \%)$ & $156(35.21 \%)$ \\
\hline Interpersonal trust mean $(95 \% \mathrm{Cl})$ & $2.41(2.36 ; 2.46)$ & $2.24(2.14 ; 2.34)$ & $2.42(2.35 ; 2.50)$ & $2.51(2.42 ; 2.60)$ \\
\hline \multicolumn{5}{|l|}{ Personal value recognition $N(\%)$} \\
\hline Yes(1) & $262(23.82 \%)$ & $154(58.78 \%)$ & $92(35.11 \%)$ & $16(6.11 \%)$ \\
\hline No(0) & $838(76.18 \%)$ & $110(13.13 \%)$ & $385(45.94 \%)$ & $343(40.93 \%)$ \\
\hline \multicolumn{5}{|l|}{ Religious behaviour N (\%) } \\
\hline Yes (1) & $681(61.91 \%)$ & $184(27.02 \%)$ & $291(42.73 \%)$ & $206(30.25 \%)$ \\
\hline No (0) & $419(38.09 \%)$ & $80(19.09 \%)$ & $186(44.39 \%)$ & $153(36.52 \%)$ \\
\hline \multicolumn{5}{|l|}{ Individual liberty $N(\%)$} \\
\hline Yes(1) & $786(71.45 \%)$ & $208(26.46 \%)$ & $326(41.48 \%)$ & $252(32.06 \%)$ \\
\hline No(0) & $314(28.55 \%)$ & $56(17.83 \%)$ & $151(48.09 \%)$ & $107(34.08 \%)$ \\
\hline \multicolumn{5}{|l|}{ Fear of competition $N(\%)$} \\
\hline Yes(1) & $466(42.36 \%)$ & $104(22.32 \%)$ & $213(45.71 \%)$ & 149 (31.97\%) \\
\hline No(0) & $634(57.64 \%)$ & $160(25.24 \%)$ & $264(41.64 \%)$ & $210(33.12 \%)$ \\
\hline \multicolumn{5}{|l|}{ Looking for a job $N(\%)$} \\
\hline Yes(1) & $583(53.00 \%)$ & $149(25.56 \%)$ & $262(44.94 \%)$ & $172(29.50 \%)$ \\
\hline No(0) & $517(47.00 \%)$ & 115 (22.24\%) & $215(41.59 \%)$ & $187(36.17 \%)$ \\
\hline \multicolumn{5}{|c|}{ FAMILY CHARACTERISTICS } \\
\hline Income level mean $(95 \% \mathrm{CI})$ & $2.85(2.75 ; 2.94)$ & $2.77(2.57 ; 2.96)$ & $2.75(2.61 ; 2.90)$ & $3.03(2.85 ; 3.21)$ \\
\hline Mother education mean $(95 \% \mathrm{CI})$ & $12.46(12.31 ; 12.62)$ & $12.78(12.45 ; 13.12)$ & $12.34(12.11 ; 12.56)$ & $12.39(12.12 ; 12.67)$ \\
\hline Father education mean $(95 \% \mathrm{CI})$ & $12.21(12.06 ; 12.36)$ & $12.35(12.04 ; 12.65)$ & $12.03(11.81 ; 12.24)$ & $12.36(12.07 ; 12.65)$ \\
\hline Parental Severity mean $(95 \% \mathrm{CI})$ & $5.93(5.79 ; 6.07)$ & $6.07(5.79 ; 6.35)$ & $5.86(5.66 ; 6.07)$ & $5.91(5.66 ; 6.17)$ \\
\hline \multicolumn{5}{|l|}{ Both parents gone abroad N (\%) } \\
\hline Yes(1) & $136(12.36 \%)$ & $39(28.68 \%)$ & $65(47.79 \%)$ & $32(23.53 \%)$ \\
\hline No(0) & $964(87.64 \%)$ & $225(23.34 \%)$ & $412(42.74 \%)$ & $327(33.92 \%)$ \\
\hline \multicolumn{5}{|l|}{ Mother gone abroad N (\%) } \\
\hline Yes(1) & $119(10.82 \%)$ & $30(25.21 \%)$ & $53(44.54 \%)$ & $36(30.25 \%)$ \\
\hline No(0) & $981(89.18 \%)$ & $234(23.85 \%)$ & $424(43.22 \%)$ & $323(32.93 \%)$ \\
\hline \multicolumn{5}{|l|}{ Father gone abroad $N(\%)$} \\
\hline Yes(1) & $200(18.18 \%)$ & $51(25.50 \%)$ & $93(46.50 \%)$ & $56(28.00 \%)$ \\
\hline $\mathrm{No}(0)$ & $900(81.82 \%)$ & $213(23.67 \%)$ & 384 (42.67\%) & 303 (33.67\%) \\
\hline
\end{tabular}

Source: Authors' own calculations in STATA 13.0 


\section{References}

Agresti, A. (2002). Categorical Data Analysis. $2^{\text {nd }}$ Edition. New York: Wiley-Interscience. ISBN 0-471-36093-7.

Akl, E., Maroun, N., Major, S., Afif, C., Abdo, A., Choucair, J., Sakr, M., Li, C., Grant, B., Schünemann, H. (2008). Post-graduation Migration Intentions of Students of Lebanese Medical Schools: A Survey Study. BMC Public Health, 8(191), 1-8, https://doi. org/10.1186/1471-2458-8-191

Andrén, D., Roman, M. (2016). Should I Stay or Should I Go? Romanian Migrants during Transition and Enlargements, in Kahanec, M., Zimmermann, K. eds., Labor Migration, EU Enlargement, and the Great Recession. Berlin: Springer, pp. 247-270 ISBN 978-3-66245319-3, https://doi.org/10.1007/978-3-662-45320-9

Balan, C. B., Jaba, E., Pârţachi, I., Chistrugă, B. (2014). Statistical Analysis of the Variation of Moldovan Migrants' Remittances during the Period 2003-2013. Studies and Scientific Researches. Economics Edition No. 06/2014, 19, 7-17., http://doi.org/10.29358/sceco. v0i19.233

Blanchflower, D., Shadforth, C. (2009). Fear, Unemployment and Migration. The Economic Journal, 119(535), F136-F182, http://doi.org/10.3386/w13506

Boheim, R., Taylor, M. P. (2002). Tied Down or Room to Move? Investigating the Relationships between Housing Tenure, Employment Status and Residential Mobility in Britain. Scottish Journal of Political Economy, 49(4), 369-392, https://doi.org/10.1111/1467-9485.00237

Canache, D., Hayes, M., Mondak, J. J., Wals, S. C. (2013). Openness, Extraversion and the Intention to Emigrate. Journal of Research in Personality, 47(4), 351-355, https://doi.org/10.1016/j.jrp.2013.02.008

Creighton, M. J. (2013). The Role of Aspirations in Domestic and International Migration, The Social Science Journal, 50(1), 79-88, http://doi.org/10.1016\%2Fj.soscij.2012.07.006

Docquier, F., Rapaport, H. (2012). Globalization, Brain Drain, and Development. Journal of Economic Literature, 50(3), 681-730, http://doi.org/10.1257/jel.50.3.681

Docquier, F., Tansel, A., Turati, R. (2017). Do Emigrants Self-Select along Cultural Traits? Evidence from the MENA Countries. CESifo. Working Paper No. 6777, pp. 1-42, https://doi.org/10.2139/ssrn.3073151

Favell, A. (2008). The New Face of East-West Migration in Europe. Journal of Ethnic and Migration Studies, 34(5), 701-716, https://doi.org/10.1080/13691830802105947

Friberg, J. H. (2012). The Stages of Migration. From Going Abroad to Settling Down: PostAccession Polish Migrant Workers in Norway. Journal of Ethnic and Migration Studies, 38(10), 1589-1605, https://doi.org/10.1080/1369183X.2012.711055

Galasińska, A., Kozłowska, O. (2009). Discourses on a 'Normal Life' among Post-accession Migrants from Poland to Britain, in Burrell, K., ed., Polish Migration to the UK in the 'New' European Union: After 2004. Farnham: Ashgate, (pp. 87-106). ISBN 978-0754673873. 
Hickey, M. (2016). Modernisation, Migration, and Mobilisation: Relinking Internal and International Migrations in the 'Migration and Development Nexus'. Population, Space and Place, 22(7), 681-692, https://doi.org/10.1002/psp.1952

Hosmer, D., Lemeshow, S. (2000). Applied Logistic Regression. New York, NY: Wiley. ISBN 978-0471356325

Huang, T.-J., Chi, S.-C., Lawler, J. J. (2005). The Relationship between Expatriates' Personality Traits and their Adjustment to International Assignments. International Journal of Human Resource Management, 16(9), 1656-1670, https://doi.org/10.1080/09585190500239325

Ivlevs, A., King, R. (2012). Family Migration Capital and Migration Intentions. Journal of Family and Economic Issues, 33(1), 118-129, http://doi.org/10.1007/s10834-011-9269-9

Jaba, E. (2002). Statistica. $3^{\text {rd }}$ Edition. Bucharest: Economica Publishing House.

Kanaiaupuni, S. M. (2000). Reframing the Migration Question: An Analysis of Men, Women and Gender in Mexico. Social Forces, 78(4), 1311-1347, http://doi.org/10.2307/3006176

Kleinbaum, D., Klein, M. (2010). Logistic Regression: A Self-Learning Text. $3^{\text {rd }}$ edition. New York, NY: Springer. ISBN 978-1441917416.

Krings, T., Moriarty, E., Wickham, J., Bobek. A., Salomońska, J. (2013). New Mobilities in Europe: Polish Migration to Ireland post-2004. Manchester: Manchester University Press. ISBN 978-0-7190-8809-4.

Lewis, V., Kashyap, R. (2013). Piety in a Secular Society: Migration, Religiosity, and Islam in Britain. International Migration, 51(3), 57-66, https://doi.org/10.1111/imig.12095

Luthra, R. R., Platt, L., Salomońska, J. (2014). Migrant Diversity, Migration Motivations and Early Integration: The Case of Poles in Germany, the Netherlands, London and Dublin. LEQS Paper No. 74, 1-65, https://doi.org/10.2139/ssrn.2428284

Niedomysl, T. (2011). How Migration Motives Change over Migration Distance: Evidence on Variation across Socio-economic and Demographic Groups. Regional Studies, 45(6), 843-855, https://doi.org/10.1080/00343401003614266

OECD - UNDESA (2013). World Migration in Figures. Available at: https://www.oecd.org/els/ mig/World-Migration-in-Figures.pdf

Otrachshenko, V., Popova, O. (2014). Life (dis)satisfaction and the Intention to Migrate: Evidence from Central and Eastern Europe. The Journal of Socio-Economics, 48, 40-49, https://doi.org/10.1016/j.socec.2013.09.008

Peterson, L. E. (2010). MLOGITROC: STATA Module to Calculate Multiclass ROC Curves and AUC from MNL Regression. Available at: https://EconPapers.repec.org/ RePEc:boc:bocode:s457181

Plopeanu, A.-P., Homocianu, D., Necula, C.-V. (2018). A Study on the Emigration Enablers of the Romanian Students in Theology. Romanian Journal of Multidimensional Education, 10(2), 180-197, https://doi.org/10.18662/rrem/55

Roman, M., Vasilescu, M. D. (2016). Explaining the Migration Intentions of Romanian Youth: Are Teenagers Different? Romanian Statistical Review, 64(4), 69-86. 
Suciu, Ş. M., Popescu, C. A., Ciumageanu, M. D., Buzoianu, A. D. (2017). Physician Migration at its Roots: A Study on the Emigration Preferences and Plans among Medical Students in Romania. Human Resources for Health, 15(6), 1-9,

https://doi.org/10.1186\%2Fs12960-017-0181-8

United Nations (2015). International Migration Report. Available at: http://www.un.org/ en/development/desa/population/migration/publications/migrationreport/docs/ MigrationReport2015_Highlights.pdf

United Nations (2017). International Migration Report. Available at: http://www.un.org/ en/development/desa/population/migration/publications/migrationreport/docs/ MigrationReport2017_Highlights.pdf

Van Mol, C., Timmerman, C. (2014). Should I Stay or Should I Go? An Analysis of the Determinants of Intra-European Student Mobility. Population, Space and Place, 20(5), 465-479, https://doi.org/10.1002/psp.1833

Williams, A. M., Jephcote, C., Janta, H., Li, G. (2018). The Migration Intentions of Young Adults in Europe: A Comparative, Multilevel Analysis. Population, Space and Place, 24(1), 1-16, https://doi.org/10.1002/psp.2123

World Bank (2018). Romania Systematic Country Diagnostic, Background Note, Migration. Available at: http://documents.worldbank.org/curated/en/210481530907970911/ pdf/128064-SCD-PUBLIC-P160439-RomaniaSCDBackgroundNoteMigration.pdf

Zumbuehl, M., Dohmen, T., Pfann, G. (2018). Parental Involvement and the Intergenerational Transmission of Economic Preferences and Attitudes. Collaborative Research Center Transregio 224. Discussion Paper No. 022, pp. 1-40. ftp://ftp.repec.org/opt/ReDIF/RePEc/ iso/leadinghouse/0148_lhwpaper.pdf 